\title{
The strong relationship between disease severity and thiol-disulphide homeostasis in patients with restless legs syndrome
}

\section{Huzursuz bacak sendromlu hastalarda hastalık şiddeti ve tiyol-disülfid homeostazı arasındaki güçlü ilişki}

\author{
Salim Neselioglu ${ }^{*}$, Yasemin Eren ${ }^{2}$, Ebru Bilge Dirik $^{3}$, Emine Feyza Yurt ${ }^{4}$, Serpil Erdogan ${ }^{4}$, Orhan Deniz ${ }^{5}$, Ozcan Erel ${ }^{1}$ \\ ${ }^{1}$ Ankara Y1ldırım Beyazıt University, Faculty of Medicine, Department of Biochemistry, Ankara, Turkey \\ ${ }^{2}$ Ankara Dışkapı Yıldırım Beyazıt Training and Research Hospital, Department of Neurology, Ankara, Turkey. \\ ${ }^{3}$ Ankara Atatürk Training and Research Hospital, Department of Neurology, Ankara, Turkey. \\ ${ }^{4}$ Ankara Atatürk Training and Research Hospital,Department of Medical Biochemistry, Ankara, Turkey. \\ ${ }^{5}$ Ankara Y1ldırım Beyazıt University, Faculty of Medicine, Department of Neurology, Ankara, Turkey.
}

Received: 27.10 .2018

Accepted: 30.10 .2018

Doi: $10.21601 /$ ortadogutipdergisi.475395

\begin{abstract}
Aim: This study was conducted to investigate thiol-disulphide homeostasis, a novel oxidative stress marker in primary restless legs syndrome (RLS) patients.

Material and Method: Thirty-eight patients and 43 healthy subjects were included in the study. Serum native thiol, total thiol, disulphide and disulphide / native thiol percent ratio levels were measured by using a novel automated method. Diagnosis of RLS was based on the criteria proposed by the International Restless Legs Syndrome Study Group (IRLSSG), and RLS severity was assessed using the IRLSSG Severity Scale.

Results: Serum native thiol and total thiol levels were significantly lower $(p<0.001 ; p=0.007$, respectively) while disulphide and disulphide/native thiol percent ratio levels significantly higher ( $p=0.017 ; p<0.001$, respectively), in patients with RLS compared with control group. Significant correlations were found between the IRLSSG Severity Scale and thiol-disulphide homeostasis parameters $(\mathrm{r}=-0.56, \mathrm{p}<0.001$ for native thiol; $\mathrm{r}=-0.51, \mathrm{p}<0.001$ for total thiol; $\mathrm{r}=0.37, \mathrm{p}=0.020$ for disulphide and $\mathrm{r}=0.60, \mathrm{p}<0.001$ for disulphide/native thiol percent ratio).

Conclusions: Decreased native thiol, increased disulphide levels and increased disulphide/native thiol percent ratio show that thiol-disulphide balance shifted to the oxidation side. Strong correlations between the IRLSSG Severity Scale and thiol-disulphide homeostasis parameters indicate that homeostasis may have a role in the pathogenesis of the Primary RLS.
\end{abstract}

Keywords: Disulphide, oxidative stress, restless legs syndrome, thiol, thiol-disulphide homeostasis 


\section{Öz}

Amaç: Bu çalışma, primer huzursuz bacak sendromu (RLS) hastalarında yeni bir oksidatif stres belirteci olan tiyoldisülfid homeostazisini araştırmak amacıyla yapıldı.

Gereç ve Yöntem: Otuz sekiz hasta ve 43 sağlıklı birey çalışmaya alındı. Serum nativ tiyol, total tiyol, disülfit ve disülfid / nativ tiyol oranları yeni bir otomatik yöntem kullanılarak ölçülmüştür. RLS tanısı Uluslararası Huzursuz Bacak Sendromu Çalışma Grubu (IRLSSG) tarafindan önerilen kriterlere gore konuldu ve RLS şiddeti IRLSSG Şiddet Ölçeği kullanılarak değerlendirildi.

Bulgular: Serum nativ tiyol ve total tiyol düzeyleri anlamlı derecede düşük (sırasıla $p<0.001 ; p=0.007$ ), disülfid ve disülfid / nativ tiyol oranı anlamlı olarak daha yüksekti (sırasıyla $\mathrm{p}=0.017 ; \mathrm{p}<0.001$ ). RLS kontrol grubu ile karşılaştırıldı. IRLSSG Önem Ölçeği ve tiyol-disülfid homeostasisi parametreleri arasında anlamlı korelasyonlar bulundu ( $\mathrm{r}=-0.56$, nativ tiyol için $\mathrm{p}<0.001$; total tiyol için $\mathrm{r}=-0.51, \mathrm{p}<0.001$; disülfid için $\mathrm{r}=0.37, \mathrm{p}=0.020$ ); $\mathrm{r}=0.60$, disülfid / nativ tiyol yüzdesi oranı için $\mathrm{p}<0.001$ ).

Sonuçlar: Azalmış nativ tiyol, artan disülfid seviyeleri ve artmış disülfid / nativ tiyol oranı, tiyol-disülfür dengesinin oksidasyon tarafına kaydığını göstermektedir. IRLSSG Önem Ölçeği ve tiyol-disülfid homeostasisi parametreleri arasındaki güçlü korelasyonlar, homeostazın primer RLS'nin patogenezinde rol oynayabileceğini göstermektedir.

Anahtar Kelimeler: Disülfid, oksidatif stres, huzursuz bacak sendromu, tiyol, tiyol-disülfid homeostazisi

\section{Introduction}

Restless legs syndrome (RLS) which is a frequent movement disorder, consists of unpleasant leg sensation at rest, especially at night. The symptoms are relieved by movement $[1,2]$. RLS affects $\% 4$ to $\% 29$ of the general population. It has primary and secondary forms. Primary form, also idiopathic form may be hereditary, whereas the causes of secondary forms are different diseases, such as depression, iron deficiency anemia, anxiety, Parkinson's disease, renal failure, and pregnancy. The pathophysiology of RLS is enigmatic. However, it is claimed quite intensively that dopaminergic pathways and impaired iron metabolism may play a role in the pathophysiology of RLS [3-5]. Nevertheless, the RLS pathophysiology is still unclear.

Recently, oxidative stress has been suggested to be associated with many diseases. Some of them are neurological diseases. There is a balance between oxidants and antioxidants in the human body. When the balance shifts towards the oxidative side, oxidative stress occurs. Reactive oxygen (ROS) species that occurs during oxidative stress cause DNA, RNA damage, lipid and protein peroxidation, and cell damage. The brain is one of the organs especially vulnerable to the effects of ROS because of its high oxygen demand and its abundance of peroxidation-susceptible lipid cells. Previous studies have demonstrated that oxidative stress plays a central role in a common pathophysiology of neurodegenerative diseases and antioxidant therapy has been suggested for the prevention and treatment of neurodegenerative diseases [6].

Thiol groups, one of the most abundant and most important antioxidant molecules in both the cells and the plasma, seems to be the main regulator of oxidative stress. The thiols are organic compounds contained in the structure of proteins. Thiol groups can form reversible disulphide bridges by the effect of oxidants. The formed disulphide bridges can be reduced to thiol groups again via the antioxidant systems in the organism. Thus dynamic thiol-disulphide homeostasis is maintained [7]. Thiol-disulphide homeostasis is involved in the pathogenesis of many diseases; cancer, coronary artery disease, diabetes mellitus, chronic kidney disease, rheumatoid arthritis, uterine myoma, celiac disease, intrahepatic cholestasis of pregnancy, basal cell carcinoma, idiopathic Parkinson's disease, Alzheimer's disease, preeclampsia, acute appendicitis, seborrheic dermatitis, migraine, age-related macular degeneration, erectile dysfunction etc. [8-13], Previously, the disulphide, native thiol, disulphide/native thiol ratio, and total thiol levels which are components of thiol-disulphide homeostasis have not been studied together in RLS. To the best of our knowledge, this study is the first report investigating thioldisulphide homeostasis in the primary RLS.

\section{Material and Method}

\section{Study Population}

Thirty-eight patients (24 females 14 males) and 43 healthy 
(26 females 17 males) subjects were enrolled in the study. Patients and healthy control groups were matched in terms of body mass index (BMI), age, and gender. The diagnosis of RLS was established based on the minimum criteria defined by the IRLSSG: (1) An urge to move the legs usually but not always accompanied by or felt to be caused by uncomfortable and unpleasant sensations in the legs (2) The urge to move the legs and any accompanying unpleasant sensations begin or worsen during periods of rest or inactivity such as lying down or sitting (3) The urge to move the legs and any accompanying unpleasant sensations are partially or totally relieved by movement, such as walking or stretching, at least as long as the activity continues (4) The urge to move the legs and any accompanying unpleasant sensations during rest or inactivity only occur or are worse in the evening or night than during the day (5) The occurrence of the above features are not solely accounted for as symptoms primary to another medical or a behavioral condition (e.g., myalgia, venous stasis, leg edema, arthritis, leg cramps, positional discomfort, habitual foot tapping). To determine the severity of the disease; Patients reporting all five IRLSSG criteria necessary for RLS diagnosis were requested to answer the 10 question IRLSSG Severity Scale (IRLSSG score, $<10$, mild RLS; 10-20, moderate RLS; $>$ 20, severe RLS; and $>30$, very severe RLS) [14].

The patient group only includes patients who are diagnosed with primary RLS. Serum iron, ferritin, vitamin B12, folic acid, liver function tests, thyroid function tests, glucose, HbA1c, creatinine, urea and hemoglobin levels were investigated to exclude the diagnosis of secondary RLS. Neurological examination and electromyography were used to determine and exclude neuropathy and radiculopathy. Exclusion criteria for the study were determined as diabetes mellitus, chronic kidney disease, rheumatoid arthritis, systemic lupus erythematosus, malignancies, gastrointestinal diseases, pregnancy, and neurological diseases, such as multiple sclerosis, polyneuropathy, Alzheimer and Parkinson's disease. The study was approved by Ankara Ataturk Training and Research Hospital Ethics Committee.

\section{Sample collection and storage}

Venous blood samples were obtained from all of the subjects through antecubital vein following overnight fasting. These samples were centrifuged at $1500 \times \mathrm{xg}$ for
10 minutes and the sera were taken apart and placed in eppendorf tubes to preserve at $-80^{\circ} \mathrm{C}$ and the study was performed within three months.

\section{Measurement of the thiol-disulphide homeostasis parameters and routine laboratory tests}

Thiol-disulphide homeostasis consists of native thiol (SH), total thiol (SH+SS), disulphide (SS) and disulphide/native thiol percent ratio (SS/SH \%) parameters. Serum native thiol and total thiol levels were measured with a recently developed, automatic measurement method by using an automated clinical chemistry analyzer (Cobas 501, Roche, Mannheim, Germany) [7]. Disulphide level and disulphide/ native thiol percent ratio (index) were generated from the measured values. The half value of the difference between total thiol and native thiol amounts gave the disulphide bond amount. The index parameter was calculated based on percent ratio of disulphide and native thiol levels. The iron, liver function tests, glucose, $\mathrm{HbAlc}$, creatinine, urea levels (Cobas c 501, Roche, Mannheim, Germany) and ferritin, vitamin B12, folic acid, and thyroid function tests (Cobas e 601, Roche, Mannheim, Germany) were measured using the commercial kit. Hemoglobin level were measured on an automatic analyzer (Sysmex XE2100, USA) by using K2 EDTA samples.

\section{Statistical Analysis}

The data were evaluated using visual (histograms and probability plots) and statistical methods (KolmogorovSmirnov test and Shapiro-Wilk test) to determine whether the data were normally distributed. Descriptive analyses were presented using mean and standard deviation (mean \pm SD) for the normally distributed variables. As the data were normally distributed, independent sample t-test and one way ANOVA were conducted to compare the parameters among groups. Correlation analyses were managed using Pearson's correlation. An overall 5\% type 1 error was used to infer statistical significance. Figures were generated using GraphPad Prism (Version 6.0; GraphPad Software Inc., La Jolla California USA).

\section{Results}

There were thirty-eight patients with primary RLS (24 females 14 males; age $47.26 \pm 14.27$ years) and 43 healthy individuals as the control group (26 females 17 males; age $45.23 \pm 9.46$ years). The distribution of age, gender, and BMI (kg m-2) were not different between the groups 
$(\mathrm{p}>0.05)$. The mean of the disease duration is $7.7 \pm 7.5$ years among RLS patients (Table 1).

The native thiol and total thiol levels were significantly lower ( $\mathrm{p}<0.001 ; \mathrm{p}=0.007$, respectively) while disulphide and index levels significantly higher $(p=0.017 ; p<0.001$, respectively), in patients with RLS compared with healthy control group (Table 1 and Figure 1).

Table 1. General characteristics and thiol-disulphide homeostasis parameters of patients with

\begin{tabular}{|c|c|c|c|}
\hline & Patient group & Control group & $\mathrm{p}$ value \\
\hline & $(\mathrm{n}=38)$ & $(n=43)$ & \\
\hline Age & $47.26 \pm 14.27$ & $45.23 \pm 9.46$ & 0.446 \\
\hline Sex (male/female) & $14 / 24$ & $17 / 26$ & 0.477 \\
\hline BMI (kg m-2) & $26.2 \pm 3.8$ & $26.1 \pm 3.1$ & 0.842 \\
\hline Duration of Disease (year) & $7.7 \pm 7.5$ & & \\
\hline Family History (n) & 13 & & \\
\hline IRLSSG severity scale & $28.12 \pm 6.52$ & & \\
\hline Native Thiol $(\mu \mathrm{mol} / \mathrm{L})$ & $376.7 \pm 45.8$ & $413.6 \pm 45.4$ & $<0.001^{*}$ \\
\hline Total Thiol $(\mu \mathrm{mol} / \mathrm{L})$ & $419.1 \pm 51.7$ & $449.8 \pm 48.5$ & $0.007^{*}$ \\
\hline Disulphide $(\mu \mathrm{mol} / \mathrm{L})$ & $21.2 \pm 5.3$ & $18.1 \pm 6.1$ & $0.017^{*}$ \\
\hline Index $(\%)$ & $5.6 \pm 1.27$ & $4.4 \pm 1.46$ & $<0.001 *$ \\
\hline
\end{tabular}
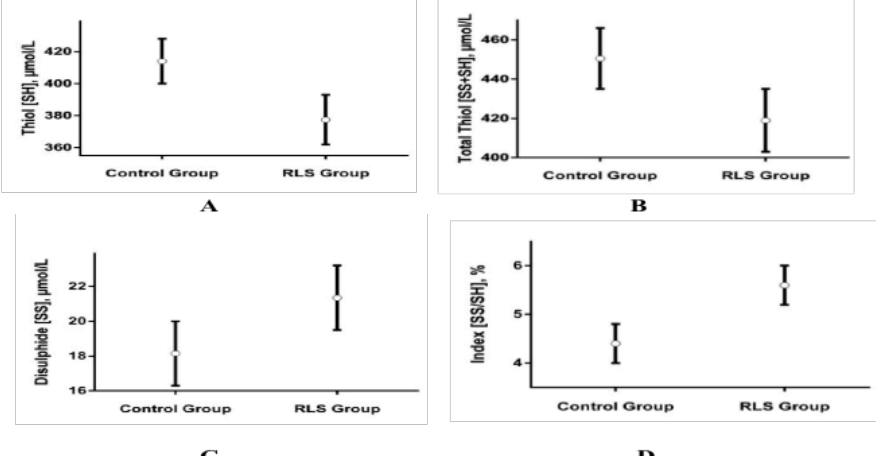

$\mathbf{D}$

Figure 1. Thiol-disulphide homeostasis values of healthy control group and RLS group

A. Serum native thiol levels $( \pm \sigma \mathrm{M})$ of the healthy control group and RLS group

B. Serum total thiol levels $( \pm \sigma M)$ of the healthy control group and RLS group

C. Serum disulphide levels $( \pm \sigma \mathrm{M})$ of the healthy control group and RLS group D. Serum index levels $( \pm \sigma \mathrm{M})$ of the healthy control group and RLS group

As shown in Table 2 and Figure 2, significant correlations were found between the thiol-disulphide homeostasis parameters and the severity of the disease symptom assessed using the IRLSSG rating scale $(r=-0.56, p<$ 0.001 for native thiol; $\mathrm{r}=-0.51, \mathrm{p}<0.001$ for total thiol; $\mathrm{r}=0.37, \mathrm{p}=0.020$ for disulphide and $\mathrm{r}=0.60, \mathrm{p}<0.001$ for disulphide/native thiol percent ratio).
Table 2. The relationship between the IRLSSG severity scale and thiol-disulphide homeostasis parameters

\begin{tabular}{|l|l|l|}
\hline & IRLSSG Severity Scale \\
\hline & $\mathrm{r}$ & $\mathrm{p}$ value \\
\hline Native Thiol $(\mu \mathrm{mol} / \mathrm{L})$ & -0.56 & $<0.001$ \\
\hline Total Thiol $(\mu \mathrm{mol} / \mathrm{L})$ & -0.51 & $<0.001$ \\
\hline Disulphide $(\mu \mathrm{mol} / \mathrm{L})$ & 0.37 & 0.020 \\
\hline Index $(\%)$ & 0.60 & $<0.001$ \\
\hline * Indicates a significant statistical difference with $\mathrm{p}<0.05 ;$ IRLSSG: \\
International Restless Leg Syndrome Study Group
\end{tabular}
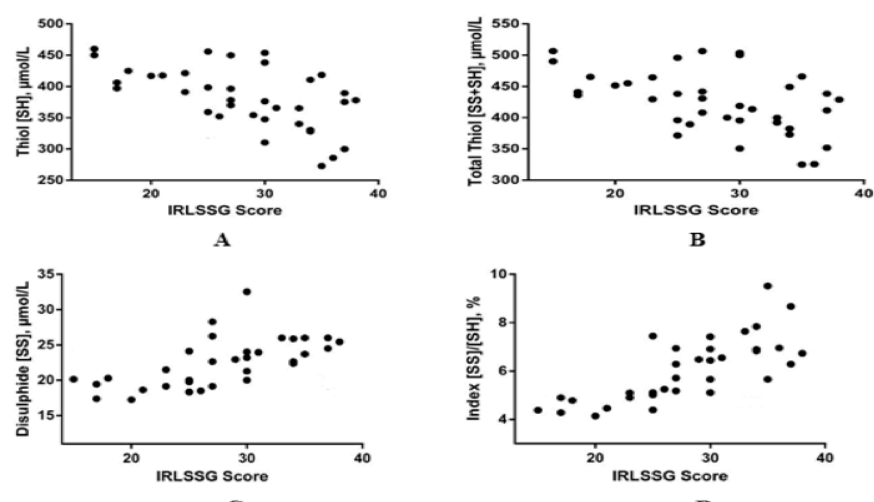

B

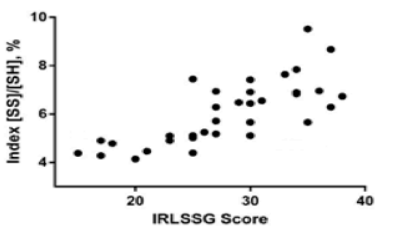

Figure 2. The relationship between the disease severity and thiol-disulphide homeostasis parameters

A. The relationship between serum native thiol levels and the disease severity

B. The relationship between serum total thiol levels and the disease severity

C. The relationship between serum disulphide levels and the disease severity

D. The relationship between serum index levels and the disease severity

As shown in Table 3 and Figure 3, Significant differences in native thiol and disulphide levels were observed among some groups when classified as mild, moderate, severe and very severe according to the IRLSSG rating scale of restless leg syndrome. Native thiol level decreased as disease severity increased (413.6 \pm 45.4 for control; 408.6 \pm 3.0 for mild-RLS; $397.4 \pm 7.5$ for moderate-RLS; $384.7 \pm 42.3$ for severe-RLS; $354.3 \pm 42.3$ for very severe-RLS). Also, Disulphide level increased as disease severity increased (18.1 \pm 6.1 for control; $19.5 \pm 0.58$ for mild-RLS; $20.4 \pm 0.7$ for moderate-RLS; $23.3 \pm 4.4$ for severe-RLS; $23.4 \pm 2.7$ for very severe-RLS). When compared with the control group, the native thiol levels of patients with severe RLS ( $p=$ $0.021)$ and very severe RLS ( $p<0.001)$ are significantly reduced. When compared with the very severe-RLS group, the native thiol levels of patients with mild RLS ( $p=0.047$ ) and severe RLS $(p=0.049)$ are significantly higher. Also, when compared with the control group, the disulphide levels of patients with severe RLS $(\mathrm{p}<0.001)$ and very severe RLS $(p=0.003)$ are significantly higher. 


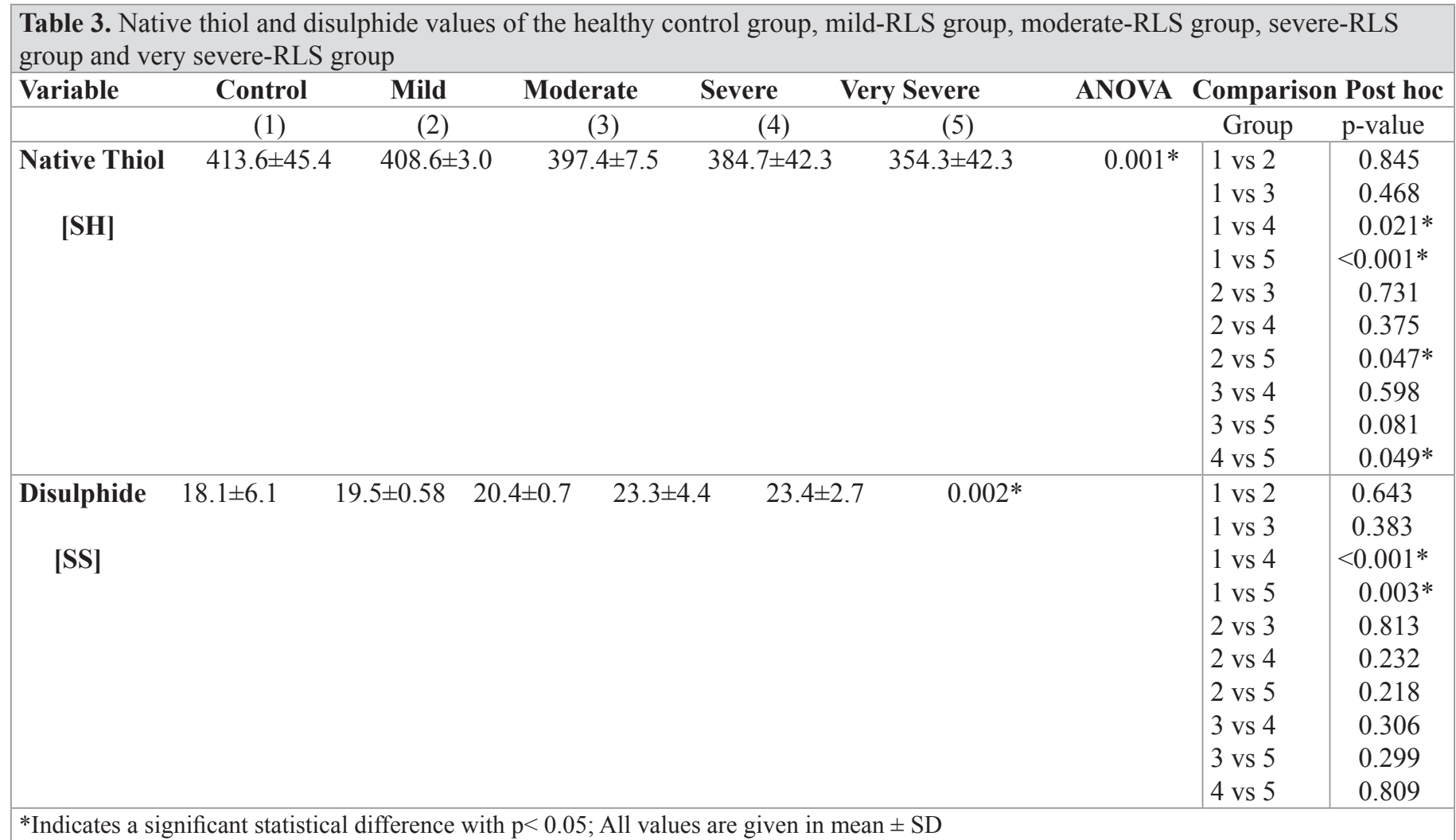

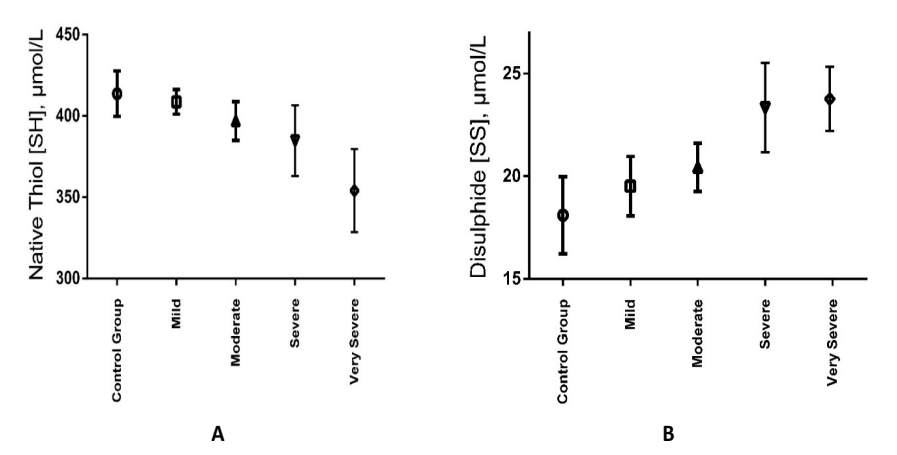

Figure 3. Native thiol and disulphide values of the control group, mild-RLS group, moderate-RLS group, severe-RLS group and very severe-RLS group A. Serum native thiol levels ( $\pm \sigma \mathrm{M})$ of the healthy control group, mild-RLS group, moderate-RLS group, severe-RLS group and very severe-RLS group B. Serum disulphide levels ( $\pm \sigma \mathrm{M})$ of the healthy control group mild-RLS group, moderate-RLS group, severe-RLS group and very severe-RLS group

\section{Discussion}

Our results suggest a strong relationship between primary RLS and a novel parameter, thiol-disulphide homeostasis. To the best of our knowledge, the present study is the first study that provided data regarding the association between thiol-disulphide homeostasis and primary RLS.

RLS is a very common movement disorder, which could cause disruption to important impairments in quality of life. Pathophysiology of the RLS had not been completely elucidated yet, but most of the researches are associated with iron metabolism, dopaminergic function, and oxidative stress [15]. In the current study, we focused on the relationship between RLS etiopathogenesis and oxidative stress-related thiol-disulphide metabolism. Previous studies have shown that increased levels of oxidant molecules and decreased levels of antioxidant molecules suggests that patients with RLS are under oxidative stress $[6,16,17]$. Therefore, oxidative stress could be an important factor in RLS pathogenesis.

Recently, there is growing interest in thiol-disulphide homeostasis test. The many diseases have been associated with a deterioration in thiol-disulphide homeostasis, such as Alzheimer's disease, Parkinson's disease, schizophrenia, coronary artery disease, acute myocardial infarction, pneumonia, acute pancreatitis, ankylosing spondylitis, and age-related macular degeneration $[8,9,18,19]$. Thiol compounds forming an important part of the antioxidant defense system are vulnerable to oxidant agents [20]. The oxidation of sulfhydryl (thiol) groups is recognized to be the earliest observable signs of protein oxidation [21]. Thiol groups can undergo oxidation reaction through oxidants and form reversible disulphide bonds. The formed disulphide bonds can again be reduced to thiol 
groups via antioxidants. This reversible balance is called thiol-disulphide homeostasis. Also, the index parameter is defined as the disulphide / native thiol ratio. This parameter indicates the direction of thiol-disulphide balance. When the index ratio increases, the homeostasis shifts towards disulphide formation whereas in the opposite situation the homeostasis shifts towards the formation of thiol [7]. Thus, both the antioxidant state (via thiol) and the oxidant state (via disulphide) can be evaluated by measuring plasma thiol-disulphide homeostasis test.

This study was conducted to investigate thiol-disulphide homeostasis, a novel oxidative stress marker in primary restless legs syndrome (RLS) patients. The native thiol level was significantly lower while disulphide and index levels significantly higher, in patients with RLS compared with the healthy control group. The reason of this, thiol groups may be converted to disulphide bonds by the effect of oxidative stress [7]. Thus, the native thiol level decreases because it is used to neutralize oxidative stress, disulphide level increases. Decreased native thiol level and increased disulphide level caused an increase in the index parameter (disulphide/native thiol percent ratio). The increase in the index parameter indicates the shift to the oxidation side of the thiol-disulphide balance. This is the first study in which the functional disulphide bond level, index level, and thiol-disulphide homeostasis are quantitatively demonstrated in RLS patient.

In previous studies, the antioxidant and oxidant capacity in plasma were investigated in patients with RLS. One of these studies has shown antioxidant capacity did not change and oxidant capacity is increased [17]. In another study, oxidant capacity is increased and antioxidant capacity is decreased similarly to the findings of our study [6]. In these studies, researchers' use of total antioxidant/ oxidant tests instead of specific antioxidant/oxidant tests, it makes the studies complicated. Because total oxidant/ antioxidant measurements can give non-specific and partially inconsistent results. However, thiol-disulphide homeostasis system investigated in our study is only based on measurement of thiol groups and disulphide bonds. Also, thiol-disulphide balance is a specific system which shows both oxidative and antioxidative status and is involved in many important metabolic processes.

In addition, As shown in Table 2 and Figure 2, significant correlations were found between the thiol-disulphide homeostasis parameters and the severity of the disease symptom assessed using the IRLSSG rating scale [22]. The IRLSSG rating scale was negatively associated with thiol levels (native thiol and total thiol), whereas positively correlated with disulphide and index levels $(r=-0.56, p<$ 0.001 for native thiol; $\mathrm{r}=-0.51, \mathrm{p}<0.001$ for total thiol; $\mathrm{r}=0.37, \mathrm{p}=0.020$ for disulphide and $\mathrm{r}=0.60, \mathrm{p}<0.001$ for disulphide/native thiol percent ratio). As shown in Table 3 and Figure 3, Significant differences in native thiol and disulphide levels were observed among some groups when classified as mild, moderate, severe and very severe according to the IRLSSG rating scale of restless leg syndrome. Native thiol level decreased as disease severity increased $(413.6 \pm 45.4$ for control; 408.6 \pm 3.0 for mild-RLS; $397.4 \pm 7.5$ for moderate-RLS; $384.7 \pm 42.3$ for severe-RLS; $354.3 \pm 42.3$ for very severe-RLS). Also, Disulphide level increased as disease severity increased (18.1 \pm 6.1 for control; $19.5 \pm 0.58$ for mild-RLS; $20.4 \pm 0.7$ for moderate-RLS; $23.3 \pm 4.4$ for severe-RLS; $23.4 \pm 2.7$ for very severe-RLS). When compared with the control group, the native thiol levels of patients with severe RLS ( $p=$ $0.021)$ and very severe RLS $(p<0.001)$ are significantly reduced. When compared with the very severe-RLS group, the native thiol levels of patients with mild RLS ( $p=0.047)$ and severe RLS ( $p=0.049)$ are significantly higher. Also, when compared with the control group, the disulphide levels of patients with severe RLS $(p<0.001)$ and very severe RLS $(p=0.003)$ are significantly higher. In other words, as the thiol-related antioxidant level increases, the severity of the disease decreases and as the disulphiderelated oxidant level increases, the severity of the disease increases. Therefore, it is clear that the thiol-disulphide homeostasis was related to the severity of the symptoms.

Although we usually focus on oxidative stress in our work, it is known that thiol groups are involved in many metabolic processes. We think that the thiol-disulphide balance may be associated with RLS disease also by different pathways in addition to oxidation.

It is known that drugs prescribed for Parkinson's disease are also used to reduce symptoms of RLS. It has been shown that L-Dopa inhibits enzymes that dysregulate thiol-disulphide homeostasis in the study by Sabens et al. [23]. Our findings have already shown that thioldisulphide homeostatis is abnormal in RLS (Table 1). The reason why L-Dopa is useful in RLS may be because it inhibits thiol-disulphide oxidoreductase enzymes which 
impair homeostasis. Also, it is remarkable that frequently used drugs in treatment such as pergolide, pramipexole, and rotigotine contain sulphur atom which is the main functional component of the thiol groups [24-26].

In our study, there was no significant difference in routine laboratory tests when the patient and control groups were compared. However, significant correlations were found between iron level and native thiol and disulphide levels. Ferritin, transferrin and transferrin receptor are important parameters related to iron deficiency anemia. The studies analyze transferrin have shown that the binding domains of iron (III) on transferrin are probably disulphide bonds on $\mathrm{N}$-domain of the transferrin formed by Cys-117 and Cys194 amino acid residues which contain thiol groups [27]. It has been reported that compounds containing thiol groups such as cysteine and glutathione mobilize iron found in ferritin in the study by Harrison [28]. Furthermore, another study has shown $\mathrm{N}$ acetyl cysteine which contains thiol group regulates intake of iron into cells by inhibition of down-regulation of transferrin receptor [29]. In addition to the above, negatively charged sulphur atoms found in thiol groups have a capacity to bind metal ions and iron is one of them. Biological iron-sulfur [Fe-S] clusters are required for in all cells to continue the life cycle [30]. It appears that thiol and iron metabolism are related to each other in many processes. In our study, there was a significant positive correlation between iron and native thiol levels $(\mathrm{r}=0.39, \mathrm{p}=0.046)$, while a significant negative correlation between iron and disulphide levels $(r=-0.40, p=0.037)$ was observed. Therefore, we have thought that iron deficiency anemia which is frequently seen in RLS may be related to thiol-disulphide homeostasis.

Consequently, the impairment of thiol-disulphide homeostasis observed in RLS disease (Table 1, Figure 1), significant correlations between thiol and disulphide parameters and the IRLSSG score indicating the severity of disease symptoms (Table 2, Table 3, Figure 2, Figure $3)$, relation to thiol-disulphide homeostasis of many drugs used in RLS treatment and the close relationship between thiol-disulphide parameters and iron deficiency anemia which is a common symptom in RLS suggest that the unclear etiology of RLS disease is highly correlated with thiol-disulphide metabolism in particular. Therefore, thioldisulphide homeostasis should be taken as a potential target in the RLS.

\section{Conclusions}

Consequently, because of decreased native thiol levels, increased disulphide and the index levels, thiol-disulphide balance in the primary RLS shifted to the oxidation side. Also, the significant correlation between increased oxidation and the severity of symptoms and signs indicates an important role of thiol-disulphide homeostasis in the pathophysiology of the disease. As a result, we have thought that to focus on thiol disulphide homeostasis can be very useful to explain etiopathagenesis of RLS and regulation of the treatment.

Conflict of interests: The authors have no conflicts of interest to declare.

Financial disclosure: There are no organizations financing our research.

Ethical approval: This investigation was approved by ethical committee of Ankara Ataturk Training and Research Hospital.

\section{References}

1. Koo, B.B., K. Bagai, and A.S. Walters, Restless legs syndrome: current concepts about disease pathophysiology. Tremor and Other Hyperkinetic Movements 2016: 6.

2. Kim, J. and A.G. Hartzema, Adherence and persistence to ropinirole, pramipexole, and gabapentin in patients with newly diagnosed restless legs syndrome. Sleep Medicine 2018; 44: 45-52.

3. Akpinar, S., Restless legs syndrome treatment with dopaminergic drugs. Clin Neuropharmacol 1987; 10: 69-79.

4. Iranzo A,. Comella CL, Santamaria J, Oertel W. Restless legs syndrome in Parkinson's disease and other neurodegenerative diseases of the central nervous system. Movement disorders: Official J Movement Disorder Society 2007; 22: 424-30.

5. Mitchell UH, Obray JD, Hunsaker E, et al. Peripheral dopamine in restless legs syndrome. Frontiers in Neurol 2018; 9: 155.

6. Baskol G,.Korkmaz S, Erdem F, Caniklioglu A, Kocyigit M, Aksu M. Assessment of nitric oxide, advanced oxidation protein products, malondialdehyde, and thiol levels in patients with restless legs syndrome. Sleep Med 2012; 13: 414-8.

7. Erel O, Neselioglu S. A novel and automated assay for thiol/ disulphide homeostasis. Clin Biochem 2014; 47: 326-32.

8. Gumusyayla S, Vural G, Bektas H, Deniz O, Neselioglu S, Erel O. A novel oxidative stress marker in patients with Alzheimer's disease: dynamic thiol-disulphide homeostasis. Acta Neuropsychiatr 2016; 28: $315-20$ 
9. Vural G, Gumusyayla S, Bektas H, Deniz O, Alisik M, Erel O. Impairment of dynamic thiol-disulphide homeostasis in patients with idiopathic Parkinson's disease and its relationship with clinical stage of disease. Clin Neurol Neurosurg 2017; 153: 50-5.

10. Gumusyayla S, Vural G, Bektas H, Neselioglu S, Deniz O, Erel $\mathrm{O}$, A novel oxidative stress marker in migraine patients: dynamic thiol-disulphide homeostasis. Neurol Sci 2016; 37: 1311-7.

11. Kundi H, Gok M, Cetin M, et al., Association of thiol disulfide homeostasis with slow coronary flow. Scandinavian Cardiovasc J 2016; 50: 213-7.

12. Altiparmak IH, Erkus ME, Sezen H, et al. Evaluation of thiol levels, thiol/disulfide homeostasis and their relation with inflammation in cardiac syndrome X. Coronary Artery Dis 2016; 27: 295-301.

13. Babaoglu E, Kilic H, Hezer H, et al. Comparison of thiol/ disulphide homeostasis parameters in patients with COPD, asthma and ACOS. Eur Rev Med Pharmacol Sci 2016; 20: 1537-43.

14. Allen RP, Picchietti DL, Garcia-Borreguero D, et al., Restless legs syndrome/Willis-Ekbom disease diagnostic criteria: updated International Restless Legs Syndrome Study Group (IRLSSG) consensus criteria-history, rationale, description, and significance. Sleep Med 2014; 15: 860-73.

15. Erden İ., Erden EÇ, Durmuş H, et al. Association between restless leg syndrome and slow coronary flow. Anatol J Cardiol; 2014: 14: 612-6.

16. Higuchi T, Abe M, Mizuno M, et al. Association of restless legs syndrome with oxidative stress and inflammation in patients undergoing hemodialysis. Sleep Med 2015; 16: 941-8.

17. Cikrikcioglu MA, Hursitoglu M, Erkal H, et al. Oxidative stress and autonomic nervous system functions in restless legs syndrome. Eur J Clin Invest 2011; 41: 734-42.

18. Altıparmak IH, Erkuş ME, Sezen H, et al., The relation of serum thiol levels and thiol/disulphide homeostasis with the severity of coronary artery disease. Kardiologia Polska (Polish Heart J) 2016; 74: 1346-53.

19. Unal K, Erzin G, Yuksel RN, Alisik M, Erel O. Thiol/disulphide homeostasis in schizophrenia patients with positive symptoms. Nord J Psychiatry 2018; 72: 281-4.

20. Turell L, Radi R, Alvarez B. The thiol pool in human plasma: the central contribution of albumin to redox processes. Free Radic Biol Med 2013; 65: 244-53.
21. Ergin M, Cendek BD, Neselioglu S, Avsar AF, Erel O. Dynamic thiol-disulfide homeostasis in hyperemesis gravidarum. J Perinatol 2015; 35: 788-92.

22. Allen RP,. Picchietti DL Auerbach M, et al. Evidence-based and consensus clinical practice guidelines for the iron treatment of restless legs syndrome/Willis-Ekbom disease in adults and children: an IRLSSG task force report. Sleep Med 2018; 41: 27-44.

23. Sabens EA, Distler AM, Mieyal JJ. Levodopa deactivates enzymes that regulate thiol-disulphide homeostasis and promotes neuronal cell death: implications for therapy of Parkinson's disease. Biochem 2010; 49: 2715-24.

24. Ma LY, Camerman N, Swartzendruber JK, Jones ND, Camerman A. Stereochemistry of dopaminergic ergoline derivatives: structures of pergolide and pergolide mesylate. Canadian Chem 1987; 65: 256-60.

25. Bennett Jr JP, Piercey MF. Pramipexole — a new dopamine agonist for the treatment of Parkinson's disease. J Neurol Sci 1999; 163: 25-31.

26. Kehr J, Hu X-J, Yoshitake T, Scheller D., Determination of the dopamine agonist rotigotine in microdialysates from the rat brain by microbore column liquid chromatography with electrochemical detection. J Chromatography B 2007; 845:.109-13.

27. Chasteen ND. The identification of the probable locus of iron and anion binding in the transferrins. Trends in Biochem Sci 1983; 8: 272-5.

28. Harrison PM. The structure and function of ferritin. Biochem Education 1986; 14: 154-62.

29. Malorni W, Testa U, Rainaldi G, Tritarelli E, Peschle C. Oxidative stress leads to a rapid alteration of transferrin receptor intravesicular trafficking. Experimental Cell Research 1998; 241: 102-16.

30. Johnson DC, Dean DR, Smith AD, Johnson MK. Structure, function, and formation of biological iron-sulfur clusters. Annu Rev Biochem 2005; 74: 247-81.

Corresponding Author: Salim Neselioglu, Ankara Yildirim Beyazit University Faculty of Medicine Department of Biochemistry, 06800, Ankara, Turkey.

E-mail: salim_neselioglu@hotmail.com 